\section{Movement Modifiers In Chinese And Their Grammatic Meanings}

\author{
Mukhamedjanova Shahbora Kamolovna \\ Department Of "Chinese Language And Literature", \\ Tashkent State University Of Oriental Studies, Uzbekistan
}

\author{
G OPEN ACCESS \\ The American Journal of \\ Social Science And \\ Education Innovations \\ JULY 2020 \\ Page No.: 170-176 \\ Volume-II Issue-VII \\ PUBLISHED: 30 JULY 2020 \\ www.usajournalshub.com/inde \\ x.php/tajssei \\ Copyright: Original content \\ from this work may be used \\ under the terms of the \\ Creative Commons Attribution \\ 4.0 licence.
}

\title{
Abstract
}

Chinese language researchers classify action verbs as part of a group of action verbs. These verbs can appear in a sentence as an independent verb predicate or as an additional part of speech as a modifier or directional morpheme.

The article discusses the modifiers of movement in Chinese, their use and grammatical meanings. The direction, result, and state meanings of the modifiers are also discussed in separate examples.

Keywords: action verb, auxiliary verb, modifier, morpheme modifier, independent verb, direction modifier, result modifier, case modifier.

\section{Introduction}

In Chinese, action verbs are used as independent verbs. These independent verbs can also be used as auxiliary verbs in conjunction with the prepositional verb. Such lexical units are called two-syllable verbs in Chinese.

When action verbs are auxiliary verbs, they act as a directing morpheme. In Chinese grammar, this morpheme is referred to as a guiding suffix, modifier [2, 1952], orientation modifier, or guiding morpheme [4, 2020], and an auxiliary element [5, 2003]. There is no significant difference between the terms. In this work, the term modifier was used and the properties of action verbs in the modifier function were studied. 
The Chinese scholar A.A. Dragunov divided Chinese verbs into two groups, dividing them into action-expressing verbs and non-action-expressing verbs. $\}$ le is not used in conjunction with it, noting that it differs from verbs denoting action. Also, action verbs are divided into several groups, one of which is the action direction group. According to A.A. Dragunov, the peculiarity of grammatical features of action verbs is that they can act as a morpheme-modifier in a sentence together with action verbs. In his work, A.A. Dragunov pays special attention to the fact that compound verbs, which act as modifiers of action direction verbs, are distinguished phonetically, that is, by the emphasis on the first syllable, the main morpheme.

According to T.P. Zadoyenko and Juan Shuin, there are verbs in Chinese that express the content of action and indicate the direction of action [6, 2004; p. 246]. The authors divide these types of verbs into two groups. The first group includes 7 verbs that describe movement in space: 进 "kirmoq" - to come in, 出 "chiqmoq" - to go out, 下 "tushmoq"- to fall, 上 "ko'tarilmoq" - to rise, 回 "qaytmoq" - to come back, 过 "kesib o'tmoq" - to cross, 起 "ko'tarilmoq" - to rise. In the second group, 2 verbs - 来 "kelmoq" - to come and 去 "ketmoq" - to leave are used to describe the action directed at the speaker [6, 2004; p. 246].

1) as an independent verb;

2) as a modifier, that is, in relation to another verb, to determine the direction of action.

For example:

他来了。[Tā láile] U keldi - He came. (Here, 来 comes as an independent verb.)

他跑来了。[Tā păo láile] U yugurib keldi - He came running . (Here the leading verb 跑, 来 is a modifier, which acts as an auxiliary verb, indicating that the action is directed towards the speaker.)

The authors conditionally call the first group of verbs a group of jinn. It was also noted that the modifier can be divided into simple and complex means of representing the direction of motion, depending on whether it consists of one or two joints. Complex means of representing the direction of motion have two modifiers, the order of which is as follows: first the modifier of group jin, then 来 and 去 are used. The two-syllable modifier in this form serves to express the direction of movement more precisely in relation to both the place and the speaker [6, 2004; pp. 321-322]. For example:

走进来 [Zǒu jìnlái] yurib kirib keldi (bu yerga) - walked in (here);

走进去 [zǒu jìnqù] yurib kirib ketdi (u yerga) - walked in (there);

拿回来 [ná huílái] qaytarib olib keldi (bu yerga) - brought back (here);

拿回去 [ná huíqù] qaytarib olib ketdi (u yerga) - took back (there). 
This means that the modifiers that represent the direction of motion have a simple and complex form. When you need to choose between simple or complex modifiers in a sentence, you need to pay attention to the syntactic structure and tone of the sentence. It should also be noted that the addition of a modifier, or other word, that modifies the direction of action, sometimes indicates which of the simple or complex modifiers should be used in a sentence $[7,571]$.

Du Hunzun's research explores the theoretical views of Chinese and Russian linguists on the use of action verbs in speech [3, 2010. p. 199]. He points out that all authors of Chinese grammar distinguish between independent and auxiliary verb functions according to the prepositional or postpositive placement of action verbs relative to other verbs. The auxiliary verb serves to identify or indicate the direction of another verb. Therefore, they should be considered as independent verbs or auxiliary verbs, depending on the syntactic function of the sentence [3, 2010. p. 42]. If the action verb acts as a modifier in the sentence, the complement comes between the prepositional verb and the modifier. For example:

小孩儿来了 [xiăo hái'ér láile] Bola keldi - The boy came.

小孩儿跑来了 [xiăo hái'ér păo láile] Bola yugurib keldi - The boy came running.

小孩儿跑进来了 [xiăo hái'ér păo jìnláile] Bola yugurib kirib keldi - The boy came running in.

In the first sentence, the verb direction of action represents the movement towards 来 [lái] landmarks and acts as a cut as an independent verb. In the second sentence, 来 [lái] is used as a modifier in a complex verb to express movement towards a landmark: 跑来 [păo lái] - an action verb with an independent meaning consists of 跑 [păo] "yugurmoq" - to run and a modifier 来 [lái]; in which the 来 [lái] following the 跑păo "yugurmoq" - to run verbs indicate its direction. In the third example, a complex means of representing 进来 [jìnlái] directions of motion - as a modifier - expresses the movement inwards, forming a three-syllable verb "yugurib kirib kelmoq" - "to run in" combined with 跑 [pǎo] "yugurmoq" - to run action verbs.

The grammatical meanings of words representing the direction of movement are very complex: most words representing the direction of movement serve to express many meanings, while words representing some direction of action serve only one type of ma. 'can represent bread. In Chinese grammar, words that indicate the direction of movement are divided into three main groups:

1) words meaning direction;

2) words meaning the result;

3) words that mean situation. 
The directional meaning of the modifiers. Direction is the basic meaning of most words, as well as the meaning of words. The direction of a word is the result of a person or object performing a certain action. For example, "来" represents the movement toward the starting point; "去" represents movement in a direction other than the point to be abandoned; "上" represents the upward movement from the lower point; "下" represents the movement from the top point to the bottom, and so on.

There is a problem in determining the starting point of the action in words that represent the direction of a complex compound action involving "来", "去", and "来", "去". How do you determine the starting point of an action?

(1) When a speaker or first person is used, the place of the speaker or "men" - "I" is the starting point. For example:

他向我走过来 [7, 547]

[Tā xiàng wǒ zǒu guòlái]

U men tomon yurib keldi - He walked towards me (the starting point is "我", which means "men" - "I" is where the speaker is standing).

我向山上跑去 $[7,548]$ 。

[Wǒ xiàngshān shàng păo qù]

Men tog'ga yuqoriga qarab yugurib ketdim - I ran up the mountain (the starting point is "我", which means "men" - "I" is where the speaker is standing).

昨天我们上口语课, 铃还没响, 老师就进教室来了[7,544]。

[Zuótiān wǒmen shàng kǒuyǔ kè, líng hái méi xiăng, lăoshī jiù jìn jiàoshì láile]

Kecha bizlarda og'zaki til darsi bo'ldi, qo'ng'iroq chalinmasidanoq o'qituvchi sinfga kirib keldi - We had an oral language class yesterday, and the teacher came into the classroom just before the bell rang (the starting point is "我们", which means "bizlar" "we" is where the speakers are).

(2) When using a third-person story, the starting point can be defined as the location of the person telling the story. For example:

小张忽然昏倒地, 大家急忙 向他跑过来 [7,547]。

[Xiǎo zhāng hūrán hūndǎo de, dàjiā jímáng xiàng tā păo guòlái]

Siao Jang kutilmaganda hushidan ketib yerga yiqildi, barcha shoshilgancha u tomon yugurdi - Xiao Jang suddenly fainted and fell to the ground, all rushed towards him (the starting point is "小张", which means "Xiao Jang"). 
看见张大夫，他急忙跑了过去 $[7,542]$ 。

[Kànjiàn zhāng dàfū, tā jímáng pǎole guòqù]

Shifokor Jangni ko'rib, (u) shoshilgancha yugurib ketdi - When the doctor saw Jang, he hurried away (the starting point is "他", which means "u" "he").

It is important to note that when the words "来" and "去" refer to the direction of motion, the motion is always directed to a specific place.

When "来" is used, the starting point is the goal of the action, for example: "车上 的 人都向他跑去", "他" is the aim of "跑".

The resulting meaning of the modifiers. Some of the words that refer to the direction of movement do not refer to the direction, but to the result of the action or the goal achieved. Words denoting most directions have the meaning of result, and words denoting some direction do not have the meaning of result alone. The meaning of the result can be divided into two types: the meaning of the main result and the meaning that is closely related to the meaning of the direction. For example, a word that represents a particular direction of action has only one meaning of result, in which case that meaning is basically the meaning of the main result; in addition to the meaning of the main result, there is another meaning of the result. For example:

\section{(the main result is meaning)}

我今天一出门就遇上了一场大雨 $[7,551]$ 。

[Wǒ jīntiān yī chūmén jiù yù shàngle yī chăng dàyǔ]

Men bugun ko'chaga chiqishim bilanoq (darhol) jalaga yo'liqdim - As soon as I went outside today, I was (immediately) caught in the rain.

这幅画儿很好看, 你贴上去吧 [7,556]。

[Zhè fú huà er hěn hăokàn, nì tiē shàngqù ba]

Bu surat juda chiroyli ekan, uni ilib qo'ya qol - This picture is so beautiful, hang it up.

\section{(non-primary result meaning)}

我闭上眼睛想休息一会儿, 听见有声, 就睁 开眼睛看了看, 什么都没有 [7, $550]$ 。

[Wǒ bì shàng yănjīng xiăng xiūxí yīhuî'er, tīngjiàn yǒushēng, jiù zhēng kāi yănjīng kànle kàn, shénme dōu méiyǒu]

Men ko'zlarimni yumib biroz dam olmoqchi edim, qandaydir shovqin eshitildi, darhol ko'zlarimni ochib qaradim, hech narsa yo'q - I closed my eyes and wanted to rest for a while, there was a noise, I immediately opened my eyes, nothing.

Status meaning of modifiers. The meaning of the state of the words expressing the direction of movement is more abstract than the meaning of the result, the meaning of the direction is the expression of the action, the development, beginning, continuation and cessation of the situation over time (with direction unrelated).

Only "上", “下”, "下来", “下去", "起", "起来", "开" make sense. The conditional meaning of the means of expressing direction loses its independent meaning and becomes specific 
to the auxiliary phrase. For this reason, most linguists have included them in their works as auxiliary words that describe the state of movement. For example:

看见地上有一条蛇, 她吓得叫了起来 $[7,553]$ 。

[Kànjiàn dìshàng yǒu yītiáo shé, tā xià dé jiàole qǐlái]

Yerda ilon yotganini ko'rib, u qo'rqqanidan baqirib yubordi - When he saw a snake lying on the ground, he cried out in fear.

听他说完，大家都笑了起来 [7,557]。

[Ting tā shuō wán, dàjiā dōu xiàole qǐlái] laughed.

U gapini tugatishi bilanoq, hamma kulib yubordi - As soon as he finished, everyone

As you can see, the meaning of the case is more abstract than the other meanings of the modifiers. In the two examples given above, the duration of the action is indicated.

\section{Conclusion}

From the foregoing, the following conclusions can be drawn:

1) In Chinese, action verbs can be used in speech not only as independent verbs, but also as auxiliary verbs, and they are called modifiers;

2 ) the modifier is divided into simple and complex means, representing the direction of motion, depending on whether it consists of one or two joints;

3) In Chinese grammar, the grammatical meanings of directional modifiers are divided into three major groups. These are direction, outcome, and status:

a) The directional meaning of the modifiers is the main meaning of most directional modifiers. In the sense of direction, the starting point of an action is determined by the position of the speaker or the person who is speaking the sentence.

b) The resultant meaning of the modifiers represents the result of the action or the result achieved. Most modifiers have the meaning of the result, and there are two kinds of the meaning of the result, which are called the meaning that is closely related to the meaning of the main result and the meaning of the direction.

c) The state meaning of modifiers is more abstract than other meanings of modifiers. The meaning of a state is basically the expression of an action, the development, beginning, continuation, and cessation of a state over time. But these meanings have nothing to do with direction.

\section{References}

[1]. Aoshuang. (2002) - Moscow. Languages of Slavic Culture.

[2]. Dragunov A.A. (1952) Studies in the grammar of modern Chinese. Part 1. - Moscow. Leningrad.

[3]. Du Hongjun. (2010) The system of prefixed verbs of movement in Russian in comparison with the Chinese language: Diss. ... Candidate of Philological Sciences. Moscow. - pp. 199.

[4]. Tan Aoshuang. (2002) Problems of hidden grammar: syntax, semantics and pragmatics of the isolating language (on the example of the Chinese language) / Tan 
Aoshuang. - Moscow: Languages of Slavic Culture.

[5]. Khamatova A.A. (2003) Word formation of the modern Chinese language. - Moscow. Muravei.

[6]. Zadoenko T.P., Huang Shuying. (2004) Basic Chinese course. Part 2. Ed. 2nd, erased. - Moscow. Muravei.

[7]. 《实用现代汉语语法(增订本)》刘月华，潘文娱，故桦. 北京2013.-1005 页.

[8]. 刘月华, 潘文娱, 故桦 Liu Yuehua, Pan Wenyu，Gu Hua. 《实用现代汉语语法 (Practical modern Chinese grammar)》. 北京: 商务印书馆, 2013.

[9]. 吕叔湘Lu Shuxian. 现代汉语八百词 (800 words of modern Chinese)，. - 北京：商务印书馆， 1997.

[10]. 马烧莹Ma Shaoin. 现代汉语趋向动词语义研究. A study of the semantics of action verbs in modern Chinese. Master's thesis. - Fudan University, 2004.

[11]. 散文佳作108篇108 masterpiece sanwen /乔萍等编著 edited by Jiao Ping.. 南京: 译林出版社, Nanjing: Yilin, 2009.

[12]. 张发明Zhang Faming. 趋向动词“来”"去"新义 (“来" and “去" new concepts of action direction verbs")// 1983. 